\title{
The prevalence of occupational asthma and rhinitis among woodworkers in south-eastern Nigeria
}

\author{
E.N. AGUWA ${ }^{1 *}$, T.A. OKEKE ${ }^{1}$ and M.C. ASUZU² \\ ${ }^{1}$ Department of Community Medicine, University of Nigeria Teaching Hospital, \\ P.M.B. 01129, Enugu, Nigeria \\ ${ }^{2}$ Department of Community Medicine, University College Hospital, P.M.B. 5116, Ibadan, Nigeria
}

\begin{abstract}
Wood dusts are known to cause respiratory disorders like rhinitis and asthma. This study was therefore done to determine the magnitude of the problem among woodworkers in south-eastern Nigeria exposed to high level of wood dust. Five hundred and ninety one woodworkers were selected using a stratified random sampling. The prevalence of woodworkrelated rhinitis and asthma were then observed in the study population. Also the peak expiratory flow rate (PEFR) of each woodworker was obtained. The prevalence of occupational rhinitis was $78 \%$, while that of asthma was $6.5 \%$. As period of woodwork increased the prevalence of rhinitis and asthma increased (rhinitis: $\chi^{2}$ trend $=53.015$, $\mathrm{df}=1, P=0.000$ ). For asthma, $\chi^{2}$ trend $\left.=19.721, \mathrm{df}=1, P=0.000\right)$. Also the PEFR significantly became low with increasing years of exposure to woodwork $\left(\chi^{2}\right.$ trend $\left.=75.965, \mathrm{df}=1, P=0.000\right)$. In conclusion the prevalence of rhinitis and asthma in woodworkers was high and significantly increased with years of working as a woodworker.
\end{abstract}

Keywords: woodwork, peak expiratory flow rate, rhinitis, asthma, wood dust, Nigeria

\section{Introduction}

Despite known and well documented respiratory health problems from exposure to wood dust such as rhinitis, asthma and adenocarcinoma of the nasopharynx, several studies globally still reveal a high prevalence of these respiratory problems among woodworkers (Wills, 1982; Bernstein, 1997). In developing countries occupational respiratory problems among wood workers appear to be worse (Jinadu, 1983). This is partly because the high prevalence of communicable diseases tends to overshadow the importance of occupational health. Recently, in southern Nigeria, small scale woodwork and furniture making industries providing employment for thousands of Nigerians are being established (Jinadu, 1983) and these utilize timber such as Mahogany, Iroko, Cedar and Mansonia. Hence due to increasing use of timber it becomes necessary to evaluate the respiratory function of Nigeria woodworkers.

Wood dusts have been known to cause a variety of health problems like rhinitis, asthma, adenocarcinoma of the nasopharynx, and skin irritation. Studies have shown high levels of wood dust exposure have been associated with respiratory disorders among woodworkers (Bernstein, 1997). Unfortunately there is paucity of the magnitude of the two conditions among wood workers in south western region.

Lung function tests are often used as objective procedures to assess the degree of air flow limitation present during expiration. Wood dust produce obstruction of the airways and the forced vital capacity $(\mathrm{FVC})$, one second forced expiratory volume $\left(\mathrm{FEV}_{1}\right)$ and PEFR are reduced. The Peak Flow Meter measures the PEFR and is often used because it is cheap and easy to carry about. Its limitations, however, include its inability to measure the FVC and FEV 1 . This study was specifically carried out to determine the extent of occupational rhinitis and asthma among south-eastern Nigerian woodworkers exposed to high level of wood dust.

\section{Materials and Methods}

\section{Study area}

The study areas were Owerri Timber Market (in Imo State) and Enugu Timber Market (in Enugu State) and both are located in the south eastern Nigeria. They are urban communities inhabited by the Igbos, one of the three major Nigerian tribes. The wood markets are divided into lines with each line comprising of several sheds. Each shed is a small scale factory employing less than 20 workers. The male wood workers are involved in carpentry, sawmill, carving, timber marketing, loading and off-loading timber while the females are only involved in carrying sawdust from the factory to places where they are sold.

\section{Sampling method}

This cross sectional study was carried out in August 2003. The sample frame was then obtained from the trade union membership register. Using a table of random numbers a total of 600 workers were selected. However only 591 workers were eventually studied; 9 workers refused to be part of the research because they felt it would disturb their work. Selection was voluntary and workers were assured of confidentiality. 
Current and past smokers and those on snuff or workers with previous history of asthma not related to present or past woodwork were excluded from the study because these could serve as confounders.

A modified semi-structured intervieweradministered questionnaire adapted from the questionnaire on respiratory symptoms approved by the British Medical Research Council's committee on Environmental and Occupational Health was used (BMC,1986). For this study, a case of rhinitis was identified in a woodworker with one or more of the following: sneezing, rhinorrhoea and/or nasal/ pharyngeal itching. A case of asthma was identified in a woodworker having wheezing and breathlessness (Braunwald et al., 2001).

Each subject immediately after answering the questionnaire had his/her height $(\mathrm{m})$ and weight $(\mathrm{kg})$ measured and recorded. Each subject was then taught how to use the Peak Flow Meter by the researcher. Three readings were taken from each subject and the highest of the readings were the accepted PEFR. The recordings were done between $12 \mathrm{hr}$ and $17 \mathrm{hr}$ after the worker had been exposed to wood dust during the day's work. the predicted PEFR for each subject using the formula; $\mathrm{y}=\mathrm{c}+\mathrm{b}_{1} \mathrm{X}_{1}+\mathrm{b}_{2} \mathrm{X}_{2}$ where $\mathrm{y}=$ predicted PEFR, $\mathrm{c}=$ constant, $\mathrm{b}_{1} \mathrm{X}_{1}=$ product of age (yrs) and coefficient of age and $b_{2} X_{2}=$ product of height $(\mathrm{cm})$ and coefficient of height (Elebute \& Femi-Pearse, 1971). The ratio of observed PEFR and predicted PEFR (\%) was calculated for each subject. Any value $\geq 75 \%$ was considered normal while $<75 \%$ was abnormal. Chisquare test for trend was then calculated.

\section{Results}

The sex distribution was 50 females and 541 males. The mean age of the females was 29.8 years $(\mathrm{SD}=$ 7.4 ) while that of males was 34.8 years $(\mathrm{SD}=10.4)$. The age range of the woodworkers was 18 to 61 years. Five hundred and thirty-six $(90.7 \%)$ were less than 40 years, $52(8.8 \%)$ were aged between 40 and 60 years while $3(0.5 \%)$ were 60 years and older. Thirty eight $(6.4 \%)$ had no formal education.

The prevalence of rhinitis was $78 \%$ while that of asthma was $6.3 \%$. There was a significant increase in prevalence of rhinitis and asthma with increasing length of wood dust exposure $\left(\chi^{2}\right.$ trend for rhinitis $=$

Table 1: Relationship between duration of exposure to woodwork and prevalence of occupational rhinitis and asthma

\begin{tabular}{lcccc}
\hline $\begin{array}{l}\text { Duration } \\
\text { (years) }\end{array}$ & No (\%) & \multicolumn{2}{l}{$\begin{array}{l}\text { Persons with occupational disease } \\
\text { Rsinitis (\%) }\end{array}$} & $\begin{array}{l}\text { Persons } \\
\text { occupational disease }\end{array}$ \\
\hline$<2$ & $98(16.6)$ & $35(8.7)$ & $1(1.9)$ & $62(46.3)$ \\
$2-5$ & $148(25.0)$ & $96(23.9)$ & $11(19.6)$ & $41(30.6)$ \\
$6-10$ & $129(21.8)$ & $99(24.8)$ & $8(14.2)$ & $22(16.4)$ \\
$>10$ & $216(36.5)$ & $171(42.6)$ & $36(64.3)$ & $9(6.7)$ \\
Total & 591 & 401 & 56 & 134 \\
\hline
\end{tabular}

$\chi^{2}$ trend for rhinitis $=64.36, \mathrm{df}=1, P=0.000$

$\chi^{2}$ trend for asthma $=23.52, \mathrm{df}=1, P=0.000$

Ethical clearance was obtained from the Ethics committee of University of Nigeria Enugu Campus. Informed consent was obtained from each participant.

\section{Data analysis}

Rhinitis and asthma were analyzed using chi square test for trend. The PEFR was analyzed by calculating
53.015, $\mathrm{df}=1, P=0.000$ while $\chi^{2}$ trend for asthma $=$ $19.721, \mathrm{df}=1, P=0.000$ ) (Table 1). There was also a significant increase in the prevalence of abnormal PEFR with increasing length of wood dust exposure $\left(\chi^{2}\right.$ trend $\left.=75.965, \mathrm{df}=1, P=0.000\right)($ Table 2$)$.

Table 2: Relationship between PEFR and duration of exposure to wood dust

\begin{tabular}{|c|c|c|c|c|c|}
\hline $\begin{array}{l}\text { PEFR } \\
\end{array}$ & & & n (years) & & \\
\hline & $<2(\%)$ & $2-5(\%)$ & $6-10(\%)$ & $>10(\%)$ & Total (\%) \\
\hline Normal PEFR & $86(87.8)$ & $95(64.2)$ & $82(63.6)$ & 77 (35.6) & 340 (57.5) \\
\hline Abnormal PEFR & $12(12.2)$ & $53(35.8)$ & $47(36.4)$ & $139(64.4)$ & 251 (42.5) \\
\hline Total & 98 & 148 & 129 & 216 & 591 \\
\hline Score for trend test & 1 & 2 & 3 & 4 & \\
\hline
\end{tabular}

$\chi^{2}$ trend $=75.965, \mathrm{df}=1, P=0.000$ 
OR (Odds Ratio for those who worked for $>5$ years and those who worked for $\leq 5$ years) of having an abnormal $\mathrm{PEFR}=3.26(2.25<\mathrm{OR}<4.72)$ at $95 \%$ confidence limits.

\section{Discussion}

Rhinitis and asthma are among the common health problems of woodworkers. Adenocarcinoma of nasopharynx also occurs more in woodworkers than in general population (Acheson et al., 1968; Wills, 1982; Anderson et al., 1976). However, adenocarcinoma is of long latency period of about 39 years, though some may develop after as little as 5 years exposure in persons who have left the industry (Acheson et al., 1968). Hence, most respiratory problems studied among woodworkers are rhinitis and asthma. Rhinitis is often of acute onset and occurs few hours after exposure while asthma may take 6 months to 3 years to occur following exposure to wood dust (Jinadu, 1983).

The prevalence of occupational rhinitis obtained in this study is higher than those of many other researchers. In eastern Poland the prevalence of rhinitis observed among furniture workers was 33.3\% (Milanowski et al., 2002). This high prevalence observed in our study may be due to poor control measures in the work place studied, the type of wood they work with or individual tendency to react differently to allergens. Observation of the working environment showed the places were poorly ventilated, with no fans to improve air circulation, no exhaust ventilation and no dust suppression method. The common woods used in the study area, especially Mansonia, are known irritants and sensitizers causing sneezing, sore throat and nose bleeding (Horner \& Wigley, 1936).

The prevalence of occupational asthma in present study was, however, similar to those reported by other researchers (Jinadu et al., 1988; Talini et al., 1998). There was a positive relationship between years of working as woodworker and occupational respiratory diseases. This was shown in both the prevalence of rhinitis, asthma and peak expiratory flow rate (PEFR). This is similar to a previous study among furniture wokers in Nigeria (Jinadu et al., 1988).

Asthma is an immunologic reaction and takes long time to develop and hence its prevalence is likely to be dependent on prolonged exposure. One reason that has been used to explain sensitizing effect of wood dust and causation of bronchial asthma is the formation of a specific antibody, Immunoglobulin E ( $\mathrm{IgE}$ ) (Waldron \& Harrington, 1980). Ahman et al. (1995) however observed that the high prevalence of respiratory symptoms may not be due to IgE mediated allergy to wood dusts. Their study among Swedish woodworkers following serum analysis of their total
Ig E, phadiatrop and radioallergosorbent test (RAST) showed no correlation between wood dust exposure and sensitization to wood dust. Similar observations have been reported by Paggiaro et al. (1981) on a study on bronchial asthma due to inhaled wood dust, Tanganyika aningre. They did not find any precipitins or specific IgE in patient sera by the immunodiffusion technique or by RAST.

Despite the pathogenesis, asthma caused by exposure to wood products gets reversed in only about $\leq 50 \%$ of cases when exposure stops. The remaining individuals experience intermittent attacks or continued chronic airway obstruction that can persist for years or indefinitely (Newman-Taylor, 1988).

Peak expiratory flow rate (PEFR) is an objective way of identifying obstructive cases of respiratory asthma even before wheezing is detected. Many researchers have observed a reduced lung function parameters e.g. PEFR, forced expiratory volume one second $\left(\mathrm{FEV}_{1}\right)$ and forced vital capacity (FVC) in woodworkers when compared to the general population (Fernandez-Rivas et al., 1997; Ige \& Onadeko, 2000). Present research shows that as the year of exposure to wood dust increases percentage of workers with abnormally reduced PEFR increases, further re-enforcing increasing presence of obstructive pathology with increasing years of exposure to wood dust. Results also show that those who worked for $>5$ years were three times more likely to have an abnormal PEFR than those who worked for $\leq 5$ years.

In conclusion, the prevalence of occupational rhinitis and asthma among wood workers is high and increases with years of exposure. It is necessary for the wood workers to be educated on associated health problems of wood dust. Also, they should be encouraged to use control measures like local exhaust ventilation, wetting the flow to prevent the dust from being airborne and use of personal protective measures such as dust masks.

\section{Acknowledgements}

We are grateful to the woodworkers and their trade union executives for their cooperation.

\section{References}

Acheson, E.O., Cowdell, R.H., Halifield, E. \& Macbeth, R.G. (1968) Nasal cancer in woodworkers in the furniture industry. BMJ $\mathbf{2}$, 587-596.

Ahman, M., Van Hage-Hamsten, M. \& Johansson, S.G.O. (1995) IgE-mediated allergy to wood dusts probably does not explain the high prevalence of respiratory symptoms among Swedish woodworker teachers. Allergy 50, 559562. 
Bernstein, D.I. (1997) Allergic reactions to work place allergens. Journal of American Medical Association 278, 1907-1913.

Braunwald, E., Fauci, A.S. \& Kasper, D. L. (2001) Harrison's Principle of Internal Medicine. $15^{\text {th }}$ ed. Mc Graw-Hill publishers, New York. pp.1920-1921.

Elebute, E.A. \& Femi-Pearse, D. (1971) Peak flow rate in Nigeria. Anthropometric determinants and usefulness in assessment of ventilatory function. Thorax 26, 597-601.

Fernandez-Rivas, M., Perez-Carval, C. \& Senent, C.J. (1997) Occupational asthma and rhinitis caused by ash (Traxinus excelsior) wood dust. Allergy 52, 196-199.

Horner, S. \& Wigley, J.E.M. (1936) A case of dermatitis veneta due to Mansonia wood (Sterculiacea altissima). British Journal of Dermatology 48, 26.

Ige, O.M. \& Onadeko, O.B. (2000) Respiratory symptoms and ventilatory function of the saw millers in Ibadan, Nigeria. African Journal of Medical Sciences 29, 101-104.

Jinadu, M.K. (1983) A Review of occupational health problems of wood industrial workers. Nigerian Medical Practitioner 5, 25-28.
Jinadu, M.K., Owolabi, S.P. \& Hassain, M.Z. (1988) Respiratory function in wood furniture workers in Nigeria. West African Journal of Medicine 7, 104-107.

Milanowski, J., Gora, A., Skorska, C., KrysinskaTraczyk, E., Mackiewicz, B., Sitkowska, J., Cholewa, G. \& Dutkiewicz, J. (2002) Workrelated symptoms among furniture factory workers in Lublin region (eastern Poland). Annals of Agricultural and Environmental Medicine 9, 99-103.

Newman-Taylor, A.J. (1988) Occupational asthma. Postgraduate Medicine 64, 505-510.

Paggiaro, P.1., Cantalupi, R., Filieri, M., Loi, A.M., Parlanti, A., Toma, G. \& Baschieri, L. (1981) Bronchial asthma due to inhaled wood dust: Tanganyika aningre. Clin. Allergy 11, 605-610.

Talini, D., Monteverdi, A. \& Benvenuti, A. (1988) Asthma-like symptoms, atopy and bronchial responsiveness in furniture workers. Occupational and Environmental Medicine 55, 786-791.

Wills, J.H. (1982) Nasal carcinoma in woodworkers: a review. Journal of Occupational Medicine 24, 526-530. 